\title{
Psicología del testigo y del testimonio
}

Alejandro Solís Espinoza

\section{La psicología del testigo y la ley}

La psicología del testigo fue uno de los primeros temas que preocupó a la naciente psicología judicial a fines del siglo XIX, ya que en casi todos los trabajos de psicología jurídica en general como en las obras de psicología forense o judicial en particular ${ }^{1}$, un capítulo importante fue este ámbito de la psicología que ha logrado un desarrollo importante, desde varias perspectivas, hasta nuestros días.

Según esta vertiente, consideramos necesario una delimitación del testigo en la ley nacional, tanto en el proceso judicial civil como penal, en los que se dan ciertas particularidades diferenciales. Asimismo, es importante el análisis del testimonio en función de sus aspectos psicológicos subyacentes. Igualmente, vinculado a todo lo anterior, resulta clave el responder a la inquietud de cómo interrogar al testigo, dentro de la práctica forense, para obtener una declaración testimonial que se aproxime a los hechos objetivos.

1 Enrico Altavilla. Psicología Judicial. Vols. I y II, Bogotá, Ed. Temis, 1975. Alejandro Ávila E. «El peritaje psicológico en los procesos judiciales». En F. Jiménez y M. Clemente. Psicología social y sistema penal. Madrid, Alianza Editorial, 1986. Adela Garzón. "Psicología social y tribunales de justicia», en F. Jiménez y M. Clemente. Psicología social y sistema penal. Madrid, Alianza Editorial, 1986. L. Muñoz y otros. Psicología. México, Ed. Grijalbo, 1960. 


\subsection{El testigo y el testimonio en la ley procesal peruana}

1.1.1 El testigo y el testimonio. En primer lugar veremos algunos aspectos generales sobre el testigo y el testimonio para revisar luego lo que dicen nuestras leyes procesales al respecto.

En el ámbito judicial, la declaración testimonial constituye un tipo de prueba o medio probatorio en la que participa una persona denominada testigo que, como dice Víctor de Santo, es toda persona física o natural "que en carácter de tercero declara en juicio sobre hechos controvertidos, que han caído sobre sus sentidos y a cuya consecuencia no se encuentra vinculado ${ }^{2}$, o dentro del fuero penal se afirma también que es una «persona física que es llamada al proceso penal para que diga lo que sabe o conoce sobre el delito, las circunstancias en que fue perpetrado y su autor [...]m. ${ }^{3}$

Dentro de este medio probatorio, un aspecto para su validez, además de otros que veremos adelante, es la cantidad de personas que acuden a testificar sobre un hecho determinado. Al respecto se conoce el principio Testis unus, testis nullus, que supone la necesidad de la concurrencia de varios testigos para la probanza de un hecho, lo que sin constituir una regla oficial vale siempre como regla de la experiencia. $\mathrm{Al}$ respecto el Código Procesal Civil vigente de 1993, señala en su Art. $226^{\circ}$ que los litigantes pueden ofrecer hasta tres testigos para cada uno de los hechos controvertidos.

La declaración que brinda el testigo es el testimonio, que como afirma Víctor de Santo, tiene una doble acepción en el campo jurídico, en el caso procesal es la declaración de un testigo, y en segundo lugar es un «instrumento que debidamente firmado y sellado (generalmente también legalizadas las firmas) reproduce y da fe de un acto o instrumento público [...]». ${ }^{4}$ Por su parte Ettore Dosi precisa que «el testimonio llamado ordinario [...] se agota con la transmisión del conocimiento de un hecho adquirido por el testigo», además agrega que el

2 Anne Anastasi. Psicología aplicada. Vol. 6. Buenos Aires, Ed. Kapelusz, 1970.

3 Amado Ezaine. Diccionario jurídico. Tomos I y II. Lima, AFA editores, $2^{\text {a }}$. Ed., 1991.

4 Víctor De Santo. Diccionario de Derecho procesal. Buenos Aires, Editorial Universidad, 1991. 
testimonio «tiene su principio en el momento del conocimiento de un hecho, y su punto de llegada en el momento de la declaración», por ello el "testimonio consta de dos fases o actividades a las que el testigo da vida: una actividad cognoscitiva (actus de praesentia) y una actividad declarativa (declaratio de scientia)". ${ }^{5}$

Sin embargo, la doctrina procesal generalmente se concentra en la indagación de la fase en que el testigo trasmite el conocimiento por él adquirido y descuida $u$ omite el momento o fase en que el testigo adquirió tal saber. Por ello el testimonio no debería ser entendido como un simple dictum, sino más bien como un acto compuesto de dos elementos: el "testis» y el "dictum», y por tanto, como un acto que se basa en la dimensión psicológica de una persona.

1.1.2. El testigo en la ley procesal nacional: en este acápite sólo enumeraremos las disposiciones del proceso civil como penal que tienen mayor implicancia con aspectos relacionados con el testigo y el testimonio desde la óptica de la psicología forense.

A. El testigo en el actual Código Procesal Civil de 1993: en él se estipula que la declaración de testigos es un medio probatorio típico (Art. 192 ${ }^{\circ}$ Inc.2), señalando además los diversos criterios para su participación, algunos de los cuales, vinculados con la temática que abordamos, son los siguientes:

«Art. $222^{\circ}$. Aptitud.- Toda persona capaz tiene el deber de declarar como testigo, si no tuviera excusa o no estuviera prohibido de hacerlo. Los menores de dieciocho años pueden declarar sólo en los casos permiridos por la ley".

"Art. $223^{\circ}$. Requisitos.- El que propone la declaración de testigos debe indicar el nombre, domicilio y ocupación de los mismos en el escrito correspondiente. El desconocimiento de la ocupación será expresado por el proponente, quedando a criterio del juez eximir este requisito. Asimismo se debe especificar el hecho controvertido respecto del cual debe declarar el propuesto".

"Art. $225^{\circ}$. Límites de la declaración testimonial.- El testigo será interrogado sólo sobre los hechos controvertidos especificados por el proponenter.

5 Ettore Dose. La prueba testimonial. Bogotá, Ed. Temis, 1986. 
«Art. $226^{\circ}$. Número de testigos.- Los litigantes pueden ofrecer hasta tres testigos para cada uno de los hechos controvertidos. En ningún caso el número de testigos de cada parte será más de seis». "Art. $229^{\circ}$. Prohibiciones.- Se prohibe que declare como testigo:

1. El absolutamente incapaz, salvo lo dispuesto en el Art. $222^{\circ}$;

2. El que ha sido condenado por algún delito que a criterio del juez afecte su idoneidad;

3. El pariente dentro del cuarto grado de consanguinidad o tercero de afinidad, el cónyuge o concubino, salvo en asuntos de derecho de familia o que lo proponga la parte contraria;

4. El que tenga interés, directo o indirecto, en el resultado del proceso; y,

5. El Juez y el auxiliar de justicia, en el proceso que conocen».

Los aspectos psicológicos y psicopatológicos relacionados con el testigo que se pueden entrever en algunas de las disposiciones citadas lo analizaremos en los siguientes rubros.

B.- El Testigo en el Código de Procedimientos Penales de 1940: dicho cuerpo legal contiene también un título especial dedicado a los testigos, en los artículos $138^{\circ}$ al $159^{\circ}$ y algunos otros. Teniendo especial importancia para este trabajo, los siguientes:

Art. $138^{\circ}$.- El Juez instructor citará como testigos:

1.- A las personas señaladas en la denuncia del Ministerio Público, o de la parte agraviada, o en el atestado policial, como conocedores del delito o de las circunstancias que precedieron, acompañaron o siguieron a su comisión;

2.- A las personas que el inculpado designe como útiles a su defensa; así como a los que especialmente ofrezca con el objeto de demostrar su probidad y buena conducta.

El número de testigos comprendidos en estos dos incisos será limitado por el Juez, según su criterio, al necesario para esclarecer los hechos que crea indispensables. El Juez, además deberá citar a todas las personas que suponga puedan suministrar datos útiles para la instrucción». Art. $142^{\circ}$.- Antes de recibir la declaración de un testigo, el Juez instructor le preguntará si profesa o no una religión; en el primer caso, le exigirá juramento, y en el segundo promesa de honor de decir la verdad. No se exigirá prestación de juramento ni promesa cuando declaren: 
1. Los testigos comprendidos en el artículo anterior

2. Los menores de dieciocho años y personas a quienes, por falta de desarrollo o por decadencia mental, se le consideren en un estado intelectual inferior al normal "[...]".

"Art. $144^{\circ}$.- Los sordomudos que sepan escribir, prestarán juramento o promesa y declaración por escrito. Los que no sepan, lo harán por signos siempre que éstos revelen hechos de fácil percepción y comprensibles a juicio del juez».

El Código Procesal Penal peruano de 1991, texto que quedó pendiente de entrar en vigencia, contiene también diversos lineamientos respecto a los testigos en los artículos $196^{\circ}$ al $214^{\circ}$, destacando algunos numerales por su importancia en la psicología del testimonio.

«Art. $196^{\circ}$.- A toda persona se le considera, en principio, hábil para prestar testimonio, excepto el inhábil natural o el impedido por la ley».

En la revisión de 1995, el texto del numeral anterior se ha mantenido prácticamente igual.

«Art. $197^{\circ}$.- La declaración del testigo versa sobre lo percibido en relación a los hechos delictuosos, y con sus circunstancias, que son materia de la investigación. Si su conocimiento es indirecto, debe señalar el momento, lugar y medio por los cuales lo obtuvo.

No se le admite al testigo expresar los conceptos u opiniones que personalmente tenga sobre los hechos y responsabilidades".

Según el Art. $205^{\circ}$, concordando con el $130^{\circ}$, el testigo mudo, sordo o sordomudo, será interrogado por escrito, y las respuestas se darán en la misma forma, excepto el sordo que contestará oralmente.

«Si el sordo no sabe leer o el mudo no sabe escribir, intervendrá en la diligencia una persona hábil, bajo juramento, para que entiendan y se hagan entender" (Art. $130^{\circ}, 2$ da. parte).

El Art. $204^{\circ}$ hace referencia a la explicación que debe hacer el Fiscal al testigo, de que corre el riesgo de caer en responsabilidad penal si falta a la verdad. Asimismo el testigo debe prestar juramento o bien promesa de honor de decir la verdad, de las que están exceptuados, entre orros, los inimputables, lo que significa que un inimputable puede 
actuar como testigo, debiéndose entonces considerar una excepción a la limitación que fija el Art. $196^{\circ}$ que se refiere al inhábil natural que no puede prestar testimonio.

El hecho de exigir juramento y advertir de las consecuencias, en caso de falsa declaración, como decía Emilio Mira y López, son de relativa importancia. Probablemente las personas más honestas y morales, y menos proclives a dar falsas declaraciones, son las que se atemorizan e impresionan más ante la amenaza y el ceremonial judicial, pero «los inmorales o amorales aquellos sobre los que en realidad se necesitaría ejercer el estímulo no reaccionan ni poco ni mucho ante él. Por ello conceptuamos superfluo el juramento y creemos absolutamente insuficientes (aún cuando necesarios) la advertencia acerca de la responsabilidad inherente al acto del testimonion. ${ }^{6}$

\subsection{Aspectos psicológicos en el testigo}

En la psicología forense, son materia de preocupación algunos aspectos concernientes a la persona del testigo, que tienen implicancias diversas en la declaración testimonial, como los relativos a su personalidad, salud mental y/o moralidad, entre otros, los que en alguna medida se contemplan en los textos legales enumerados.

\subsubsection{Personalidad del testigo}

Según los estudios de la personalidad, existen variantes de esta dimensión humana que influyen en la conducta de modo diverso. Al respecto se puede considerar que el contenido testimonial de las personas inestables, sugestionables, volubles, prejuiciosas, debe ser tomado con cuidado porque en ciertos casos pueden carecer de valor. Probablemente, una persona estable emocionalmente, carente de prejuicios, con rasgos marcadamente flemáticos (introversión), sea un testigo más confiable o "ideal", con las limitaciones del caso. Sin embargo, la personalidad del testigo tiene además sus particularidades en función de otras condiciones como la edad, sexo, instrucción, entre otras.

6 Emilio Mira y López. Manual de psicología jurídica. Buenos Aires, Ed. El Ateneo, 1991. 
A.- Personalidad y edad del testigo: no podemos desconocer que la personalidad de un niño, de un adolescente, del adulto y de un anciano tienen sus diferencias importantes. Por ello, generalmente se considera que dado el carácter de inmadurez psicológica del niño y en parte del adolescente, su personalidad no muestra estabilidad y configuración definitivas, aunados a sus peculiares características psíquicas y su menor experiencia psicosocial, salvo excepciones. Al respecto nuestro Código Procesal Civil vigente señala como la prohibición de declarar como testigos a los menores de dieciseis años, cuando dice que no puede declarar el absolutamente incapaz (Inc.1. Art. 229० C.P.C.), lo que se debe concordar con el Código Civil que estipula que los menores de 16 años son absolutamente incapaces (Art. $43^{\circ}$ C.C., Inc. 1).

A contrario sensu, ello significa que está permitida la declaración como testigo del mayor de dieciséis años, pero que concordado con el Art. $222^{\circ}$ del C.P.C., esta capacidad de testificar de los menores de dieciocho años en un proceso civil sólo será en los casos admitidos por ley.

El Código Civil señala sin embargo otras excepciones concernientes al menor de dieciséis años de edad, por ejemplo la mujer o varón mayores de catorce años dejan de ser incapaces (Art. $46^{\circ}$ C.C), a partir del nacimiento de hijos, para realizar determinados actos como el reconocer a sus hijos u otros relacionados con su tenencia y alimentos.

Otra excepción es la que autoriza al Juez civil la posibilidad de ordenar la comparecencia a la audiencia de pruebas de un menor, de edad (Art. $194^{\circ}$ C.P.C), caso en el que debe tener discernimiento, lo que se puede concordar en parte con lo dispuesto por el artículo $1358^{\circ}$ del C.C.: «Los incapaces no privados de discernimiento pueden celebrar contratos relacionados con las necesidades ordinarias de su vida». En este caso dichos textos no diferencian entre incapaces absolutos (menores de dieciséis años) e incapaces relativos (menores de dieciocho años), por lo que es factible que algunos menores de dieciséis años que tengan discernimiento puedan participar en tales actos.

En este caso, la idea de discernimiento tiene sus antecedentes en el Derecho romano y ha tenido influencia hasta nuestra época, sobre todo en lo concerniente al Derecho de menores, con el que se alude prácticamente a la capacidad de comprensión y de distinguir lo bueno y lo malo, o lo lícito e ilícito, dentro de ciertos términos relativos que puede poseer un menor de dieciocho años de edad, pero cuyo límite infe- 
rior de edad no tiene una delimitación precisa, en base a las normas señaladas en los cuerpos legales aludidos.

El Código de Procedimientos Penales de 1940 admite la potestad de declarar como testigo a los menores de dieciocho años de edad, con la salvedad que no se les exija juramento o promesa de honor de decir la verdad. En este caso no se fija tampoco el límite mínimo de edad hasta la que se admitiría testificar, quedando su delimitación según el caso particular.

El Código Procesal Peruano de 1991, cuya vigencia ha quedado diferida, estipula que no puede prestar testimonio el inhábil natural, empleando una denominación no muy precisa, pero que se interpreta en todo caso como incapacidad, dentro del cual se hace alusión a una condición de ausencia de capacidad por diversas condiciones. Pero el agregado de "natural" da a entender a su vez a un estado relacionado a la naturaleza humana, en la que cae la madurez psicobiológica que está en función de la evolución temporal del sujeto, por lo que este impedimento incluiría al menor de edad incapaz absoluto. Sin embargo, si tomamos en cuenta el inciso 2 del Art. $204^{\circ}$ de dicho cuerpo legal, se permite declarar a los inimputables, y los menores de dieciocho años lo son, sin la exigencia de juramento o promesa de honor.

En todo caso para admitir la participación testimonial de un menor de edad se deben tener en cuenta su edad (niño, púber, adolescente), y sus particularidades personales. $\mathrm{Al}$ respecto, es posible que la declaración de un menor pueda ser más confiable que la declaración de un adulto con determinados rasgos de personalidad inadecuados, pero también un niño puede ser más influenciable y fantasioso.

Teniendo en cuenta la personalidad del anciano, se debe considerar que la involución psicobiológica que sufre influye en su capacidad testimonial, por ello se debe valorar la validez o relatividad de su testimonio, aunque las leyes procesales no dicen nada al respecto. Nos estamos refiriendo, en este caso, al anciano que no tiene alteraciones patológicas como las demencias seniles $u$ otras que a veces se presentan en esta cdad y que originarían una incapacidad definida. Pero de todos modos, al margen de tales situaciones -que lo veremos más adelante- una persona de la llamada tercera edad, cuanto más avanza en la etapa provecta, presenta ciertos cambios en su personalidad y sobre todo en su capacidad perceptual (viso-auditiva), y en su capacidad mnémica, entre otras, cuya credibilidad testimonial, en ciertos casos puede ser más dudosa 
que la de -por ejemplo- un niño. Al respecto A. Langeluddeke afirma que a veces se cree erróneamente en la exactitud de las declaraciones de un anciano, porque "puede causar una impresión de completa claridad mental a quien solamente les haga preguntas de la vida diaria; pero tan pronto como se les trata más de cerca, se nota que detrás de una fachada exterior bien conservada domina un asombroso vacío y que no saben dar una contestación exacta a las preguntas más sencillas [..] » ${ }^{7}$. Emilio Mira decía también al respecto, refiriéndose al septuagenario, «que a medida que disminuye en ellos su precisión de observación y testimonio, crece en cambio su convencimiento en la certeza de sus declaraciones". 8

B.- Personalidad y sexo: determinados autores han señalado que se pueden encontrar diferencias importantes en la testimonial de un varón respecto a una mujer. Incluso ya William Stern había efectuado algunos estudios sobre el particular, y las opiniones eran que un varón era más confiable en su testimonio con respecto a una mujer, aunque se consideraba también que ésta era mucho más exacta en los detalles. En este caso debemos precisar que actualmente estas ideas genéricas no pueden ser criterios válidos para evaluar la mayor fiablidad de las testimoniales en función del sexo.

C.- Personalidad y grado de instrucción del testigo: si bien el testigo declara sobre hechos percibidos o de los que obtuvo información en momentos cercanos al hecho, y que están supuestamente almacenados en su memoria a largo plazo de tipo episódico, tales hechos se supone que fueron aprehendidos y retenidos en función a su madurez biológica y personalidad en general, o según una óptica masculina o femenina (prejuicios e intereses en función del sexo). Dentro de este contexto no deja de tener implicancia también el grado de escolaridad o capacitación técnica o de otra índole que posee el testigo, para el conocimiento más o menos objetivo del hecho materia del testimonio.

Es necesario valorar el testimonio que depone un analfabeto, o de alguien que tiene conocimientos medios o de uno que cursa instrucción superior, o un profesional determinado. Probablemente la mayor o menor experiencia y práctica escolar puede intervenir en alguna medida, en la direccionalidad de la percepción del hecho.

7 Albrecht Langeluddeke. Psiquiatría forense. Madrid, Espasa Calpe, 1972.

8 Emilio Mira y López. Op. cit. 
Asimismo el testigo que posee un nivel cultural medio o alto o un grado de escolaridad similar, posiblemente puede tener un nivel de mayor comprensión y posibilidad de evocar mejor o comunicar con mayor claridad los acontecimientos o situaciones materia del hecho testimonial. Esto quiere decir que para valorar el grado de credibilidad del testimonio es también importante esta condición personal. Sin embargo al igual que en los otros factores personales, no se puede partir, en la generalidad de los casos, de un criterio a priori, sino que la importancia y validez del testigo debería ser evaluado en cada caso particular.

De los elementos personales que hemos señalado, podemos trazar un perfil hipotético de testigo óptimo, en el que se consideran algunas condiciones que son indicadores positivos de un testimonio más objetivo y creíble, esto es: un adulto, varón, de personalidad «normal» (flemático), honesto y de cultura mayor que el término medio. Sin embargo, no escapa la posibilidad de poner en duda la validez de un testigo ideal en algunos casos, por razones tanto del proceso mismo de cómo se obtuvo y conservó en la memoria el dato objeto del testimonio, como del grado de compromiso u otros aspectos que lo vinculan con alguna de las partes en el proceso.

Además, el testigo que interviene en un proceso judicial depende de lo que éste tenga que decir en cada caso en litis, y este testigo citado depende del azar, y no en función a los criterios personales de mayor objetividad que idealmente serían de esperar.

\subsubsection{Salud mental del testigo}

Los trastornos mentales que pueda presentar este actor «invitado" al proceso judicial tendrá mayor repercusión en la validez o credibilidad de su testimonio, en casos que se le permita deponer. Aunque en principio se puede partir de la idea que algunas personas con alteraciones mentales estarían vedadas para prestar declaración testimonial, sobre todo en el proceso civil; sin embargo en el caso penal, según el inciso 2 del Art. $142^{\circ}$ del C.P.P. se puede admitir la declaración de personas en estado de «decadencia mental [...]», inimputables. Sin embargo, no podemos olvidar que estos trastornos incluyen diversos cuadros con alteraciones muy variadas ${ }^{9}$, algunos de los cuales sí inhabilitarían para testificar.

9 E.F.P. Bonnet. Psicología y psiquiatría forenses. Tomo I, Buenos Aires, López 
A.- Testigo y trastornos de personalidad: dentro de los trastornos mentales, los «Trastornos específicos de personalidad», llamados hace algunas décadas atrás personalidades psicopáticas, ${ }^{10}$ pueden tener repercusión en la fiabilidad de su declaración testimonial. En el caso de la actuación testimonial de personas con estos trastornos, su participación como testigos debe ser tomado con reserva, sobre todo tratándose de trastornos de personalidad antisocial o disocial, cuyas características de anormalidad o desviación, evidentemente pueden poner en tela de juicio la objetividad y veracidad de su testimonial, lo que no significa tampoco que puedan declarar válidamente, pero el problema queda entonces en manos del juez para valorar la testimonial de dicha persona, siempre y cuando se tenga una información previa del trastorno que sufre.

Probablemente merezca también reparos la declaración testimonial de un testigo con "trastorno de personalidad histérica» o "histriónica», antes llamado también "psicópata necesitado de estimación» por Kurt Schneider, ${ }^{11}$ por la inseguridad del contenido que puede relatar como parte de su testimonio, en caso de actuar como testigo, y sobre todo por su tendencia pseudológica, ya que como dice A. Langeluddeke son inadecuados como testigos los llamados "pseudologistas" que mezclan en su recuerdo la verdad y la fantasía, hasta el punto que ellos mismos terminan por creer en la verdad de sus embustes». ${ }^{12}$

Asimismo, no serían fiables aquellos que por su trastorno de personalidad paranoide pueden tergiversar los hechos objeto de su testimonial. Sin agotar las anotaciones a los diversos trastornos de personalidad y sus repercuciones cuando actúan como testigos, debemos señalar que en los textos procesales no se considera ninguna anotación al respecto, salvo el referirse al incapaz o einhábil natural", sobre la posibilidad de adoptar alguna previsión o duda en caso de testigos con algún trastorno de personalidad importante dentro de este contexto.

Libreros Editores, 1983. Roberto Serpa. Tratado de psiquiatría forense. Bogotá, Ed. Temis, 1979. Alejandro Solís E. "Aspectos psicopatológicos de la inimputabilidad" en: Revista Peruana de Ciencias Penales. Lima, 1994, No 4.

10 Kurt Schneider. Las personalidades psicopáticas. Madrid, Ed. Morata, 1965.

11 Kurt Schneider. Op. cit.

12 Albrecht Langeluddeke. Op. cit. 
B.- Testigos con trastornos psicóticos: generalmente la mayoría de psicosis o locuras producen una alteración grave en la capacidad mental del sujeto, con sus peculiares características cada psicosis.

Dentro de las psicosis orgánicas destacan en primer término una variedad de psicosis seniles y preseniles, una de cuyas características es la demencia del paciente, esto es un deterioro del intelecto por factores orgánicos neurológicos, que ocurre en la etapa senil o presenil de algunas personas, aunados a otros tipos de alteración en el juicio y/o en el afecto. En estos casos es evidente que una persona con tales psicosis no puede ser apta para declarar como testigo, y dentro del campo judicial el Código Procesal Civil cuando señala que no pueden ser aptos para declarar como testigos los absolutamente incapaces, incluye en forma tácita esta psicosis, sólo que el conflicto se puede presentar cuando algunos testigos con psicosis senil o presenil no hayan sido declarados interdictos, o bien estándolos el Juez no tiene conocimiento de ello. Por tales razones es importante que el magistrado posea alguna información mínima sobre psicología y psicopatología, para que pueda tomar una decisión más objetiva en tales circunstancias. En todo caso, la edad provecta de un testigo puede ser un indicador para auscultar si éste sufre alguna psicosis senil o presenil.

En el grupo de la psicosis orgánica, también resultan importantes las psicosis debidas a drogas y las psicosis alcohólicas, con sus cuadros específicos. En todos estos procesos se produce una alteración del juicio, y si se trata de una persona citada como testigo, su declaración no tendría validez probatoria en ciertos casos. Al respecto, Charles Morris dice que generalmente los resultados demuestran que el alcohol dificulta la capacidad de codificar nueva información, y en «los casos extremos de alcoholismo crónico puede presentarse la "psicosis de Korsakoff", trastorno que se caracteriza por grandes defectos de la memoria y por desorientación. Los que la sufren pueden olvidar hasta su nombre, de donde vienen o donde se encuentran». ${ }^{13}$

Entre los trastornos psicóticos no orgánicos, llamado a veces psicosis endógenas, que son cuadros bastante graves, sin una base orgánica definida, como por ejemplo la esquizofrenia y también la psicosis afectiva, que en caso de afectar a un testigo bien sea en la época que percibió los hechos o en la etapa de la declaración testimonial, nos

13 Charles Morris. Psicología: un nuevo enfoque. México, Prentice Hall, 1987. 
indicará que tampoco sus declaraciones, en estos casos, pueden ser válidas como elementos de prueba del hecho objeto del proceso. Sobre todo los casos de hipomanía o de "maníacos leves" son los más peligrosos, porque pueden proceder a inculpaciones infundadas, que ellos consideran verdaderas y que los mantienen tenazmente y que pueden convencer al profano de su "veracidad".

En estos y otros casos de psicosis, en los que las personas sobre todo sufren una distorsión de la razón, si bien pueden no manifestar ningún proceso agudo del trastorno mental que padecen, en el momento del acto testimonial, y que a la vista de un profano puede parecer una persona "normal», los juicios que emiten o los informes que aporta de la experiencia que señalan haber vivido, en su declaración testimonial, pueden estar sesgados y no poseer validez. Sin embargo esto no quiere decir que el total de sus declaraciones sean alterados, ya que en parte pueden estar referidos a hechos y datos ciertos, pero es probable que estén mezclados o junto a datos y hechos distorsionados, y el problema resulta en todo caso, en el supuesto de su participación como testigo, la dilucidación de los datos objetivos de los datos distorsionados. En todo caso esto nos lleva a plantear que el Juez debe tener algún conocimiento sobre la materia, y que en caso de sospecha de anormalidad psicótica en el testigo, pueda tomar las providencias del caso o solicitar la participación de un perito.

C.- Testigos con retraso mental: en este punto debemos indicar, que el cuadro genérico de retraso mental era denominado hasta los años 60 del siglo XX con el nombre de oligofrenia, el que incluía tres grados: el "débil mental», el «imbécil" y el “idiota». Actualmente, dentro de los casos de retraso mental se consideran generalmente cuatro grados: retardo mental discreto o leve, retardo mental moderado, retardo mental grave y retardo mental profundo. De estos diversos niveles de retraso mental, los casos de retraso grave y profundo presentan una incapacidad muy notoria, que los imposibilita para prestar algún testimonial. En el supuesto del retardo mental moderado la capacidad intelectual es escasa, y aunque pueden haber aprendido a comunicarse, casi no habrá progresado más allá de un segundo grado de primaria, y su testimonial sería de relativa validez, según la mayor, escasa o nula práctica o entrenamiento educativo que haya recibido. En el caso del retraso mental ligero o leve, su testimonio puede tener algún grado de mayor certeza, por tener una capacidad que les puede permitir alcanzar hasta un nivel escolar de sexto grado de primaria, aunque con dificultades, y poder 
desarrollar algunas habilidades prácticas, dependiendo también del caso concreto, si ha tenido educación especial o ausencia de entrenamiento educativo.

Según nuestra legislación Procesal Civil al considerar privados de actuar como testigos a los absolutamente incapaces, incluye tácitamente los grados de retraso mental profundo y grave, siendo discutible los moderados y leves, en el supuesto que hayan sido declarados incapaces en un proceso de interdicción civil, lo que plantea la interrogante ¿qué hacer ante casos de no declarados interdictos o incluso hasta interdictos de los que no se tiene conocimiento de tal hecho?

Nuestro Código Procesal Penal de 1940, prácticamente admite la declaración testimonial de estos casos (Art. $142^{\circ}$ ), cuando se refiere a las personas que por falta de desarrollo o por decadencia mental, «se les consideren en un estado intelectual inferior ai normal [...]", a quienes no se les exigirá prestar juramento ni promesa. Sin embargo, el Código Procesal de 1991, en su artículo $196^{\circ}$, dispone que no puede declarar como testigo el «inhábil natural» o el «impedido por la ley», en cuya primera parte consideramos que entran los casos de deficiencia intelectual, como personas inhábiles para actuar como testigos, salvo lo dispuesto por el Inc. 2 del Art. $204^{\circ}$, que en la práctica incluiría a los retardados leves y a veces a los moderados.

En la experiencia alemana, Albrecht Langeluddeke, plantea que ni una enfermedad mental ni una «debilidad mental» (retardo mental leve) excluyen la prestación de juramento, y que si la declaración es fidedigna o no tiene que ser examinado caso por caso, y como obligación del juez que efectúa el interrogatorio, y sólo por excepción se encomendaría este problema al examen pericial. Asimismo considera que es "preciso admitir plenamente que, por ejemplo, los débiles mentales, por razón de la edad, no tienen una idea suficiente de la importancia y de la esencia del juramento, como tampoco la tienen los enfermos delirantes. Pero lo que se pregunta en este momento es cómo puede mantenerse la credibilidad de sus declaraciones. Cuestión ésta que en la práctica no siempre es fácil de contestar, porque enfermos mentales pueden prestar declaraciones completamente veraces; pero como la verdad y la fantasía están tan entrelazadas en sus declaraciones, cabe que la fantasía, erróneamente, sea considerada como verdad». ${ }^{14}$

14 Albrecht Langeluddeke. Op. cit. 
D.- Testigos farmacodependientes: si aceptamos que una persona normal, en cuanto trata de rememorar hechos acaecidos en el pasado, no siempre tiene un recuerdo fidedigno, sino que puede sufrir diversas distorsiones; tratándose de una persona drogadicta o farmacodependiente, con alteraciones muy diversas en su personalidad y/o en su percepción, además de estar bajo dependencia a la droga que consume, podemos considerar que su actuación como testigo tendrá limitaciones en la calidad de su recuerdo y por consiguiente en la validez de su testimonio. Charles Morris dice al respecto, que por ejemplo «la mariguana al parecer deteriora la capacidad de codificar y almacenar datos en la memoria a largo plazom. ${ }^{15}$

E.- Testigo alcohólico: en este caso la dependencia alcohólica afecta la personalidad del adicto, y muchas veces una de las secuelas de la ingesta crónica de alcohol es también la alteración de las funciones mnémicas, que son fundamentales tratándose del testimonio, por ello el juez deberá tener en cuenta, si este fuera el caso, para considerar la declaración de una persona con dicho trastorno, no obstante que las normas legales no precisan en forma específica limitaciones para casos de esta naturaleza. Como dice el citado Charles Morris, en "general los resultados muestran que el alcohol entorpece la capacidad de codificar nueva información [...]. El consumo de grandes cantidades de licor puede ocasionar una notable pérdida de la memoria. En algunos casos, todo lo que se dijo o hizo bajo los efectos del alcohol queda totalmente suprimido. El individuo quizá no recuerda ni siquiera hechos de gran importancia: como el de haber golpeado a alguien». ${ }^{16}$

F.- Testigos neuróticos: en estos trastornos mentales, en que no existe un deterioro o distorsión notable del juicio en el paciente, sino más bien trastornos emocionales, sobre todo con fondo ansioso acentuado, podrían en general participar como testigos. Salvo algunos casos muy acentuados o algunos cuadros específicos que pueden tener incidencia en las funciones mnémicas, como el de la neurosis histérica tipo disociativa, en la que pueden ocurrir amnesias, sonambulismo, fugas y fenómenos de personalidad múltiple, que alterarían la percepción clara de los hechos objeto del testimonio, con repercusión en una declaración que no sería muy objetiva. 


\subsubsection{Moralidad del testigo}

Sobre este particular diremos, que en términos generales es más confiable una persona honesta frente a una persona con algún grado de deshonestidad o incluso de criminalidad, lo que significa que «el testimonio como dictum deriva su valor del testis, lo que en otros términos supone que el testimonio que interesa al juez está en función de la confranza que se tenga en el testigo. En otros términos Testibus, non Testimoniis Creditur o "tanto vale el dictum cuanto vale el testis».

Esto sin embargo es una generalización, que indica la posibilidad que las personas honestas, en porcentaje mayor sean más sinceras o fiables que las deshonestas. No obstante ello, de acuerdo a la situación concreta, puede una persona deshonesta prestar una declaración objetiva y fiable, mientras que una persona honesta, por motivos especiales diversos puede tergiversar su declaración. Además hay que anotar que la frabilidad en la persona no es elemento suficiente para tener credibilidad en los informes que depone, porque puede alterarse por distorsiones de su memoria a largo plazo, como veremos más adelante, y que están al margen de su voluntad o buena fe. Al respecto Miguel Herrera dice que las «virtudes morales son capitales en la estimación testimonial. Pero las virtudes que adornan una personalidad, pueden empañarse por móviles pasionales subconscientes generados de actitudes prejuiciosas. Los testimonios, no pueden distinguirse en forma radical y absoluta como buenos o malos». ${ }^{17}$

Nuestra legislación procesal, de gran parte del siglo XX, sobre todo del Código de Procedimientos Civiles de 1912, consideró que estaban prohibidos para declarar como testigos:

- Las personas indignas de fe por razón de malas costumbres notorias o de vagancia.

- Los condenados por falso testimonio.

- Los que están sujetos a mandamiento de prisión.

Si bien tales prohibiciones encuadraban, en alguna medida, dentro del ámbito de la moralidad y que les impedía participar como testigos, tales limitaciones merecían algunas observaciones:

17 Miguel Herrera. Psicología y criminología. Buenos Aires, Ed. Bibliográfica Omeba, 1966. 
En el primer caso, "las malas costumbres notorias" que hacen indigno de fe, no constituyeron criterios objetivos y claros, sino más bien subjetivos y mudables en función del ámbito social y la época. Además, en el supuesto que fuera una caracterización precisa, sobre todo en distritos judiciales con poblaciones masivas y anónimas, su apreciación resulta difícil. En cuanto a la segunda parte de la indignidad por razón de "vagancia» del propuesto como testigo, resulta también difícil de aceptar en nuestros días, porque tampoco existe un criterio objetivo para precisarlo, y si además si consideramos incluso que la llamada «Ley de vagancia» del año de 1924 fue derogada en la década del ochenta, no es posible aceptar este criterio como limitación para testificar.

En cuanto a los condenados por falso testimonio, los elementos para su comprobación eran probablemente más objetivos y factibles de acreditarse, lo mismo podría decirse de los que estaban sujetos a mandamiento de prisión, aunque les alcanzaba objeciones similares a las hechas líneas antes, y por ser además muy genéricas.

El Código Procesal Civil vigente ni el Código de Procedimientos Penales de 1940, señalan alguna limitación clara vinculada con la moralidad del testigo, pero creemos que el juez y en función de las tachas que pueda interponerse por la parte interesada, en el caso respectivo, podría valorar la imparcialidad y confiabilidad del testigo cuestionado por razones de duda en su moralidad para testificar. Por ello, Emilio Mira propone que se haga un "previo reconocimiento de la personalidad del testigo y de su posición en la situación de testimoniar, con el fin de poder predecir cuál ha de ser la intención que le guía al hacerlom. ${ }^{18}$

En suma, el testimonio en el ámbito judicial, constituye un medio de prueba sujeto a muchas dudas, sin negar que de acuerdo a la naturaleza del hecho o materia de probanza, en ciertos casos la duda será escasa o nula y en otros debe ser tomado con las precauciones debidas. Por ejemplo, si alguien declara que la señora $\mathrm{X}$ y el señor $\mathrm{Z}$ vivían en un departamento que estaba al lado del suyo, y que esto fue durante meses o años, este hecho genérico es verosímil, por lo tanto es probable que esté sujeto a un mínimo error. Pero si una persona declara que el señor Y junto con otros, estaba bebiendo cerveza el día sábado 11 de 
julio de 1992, en horas de la tarde. Los datos relatados pueden estar sujetos a distorsiones en cuanto al día y/o al año y la hora, o en cuanto al hecho de si efectivamente bebía cerveza, porque el señor Y pudo haber tenido un vaso de gaseosa y sus acompañantes cerveza.

\section{Aspectos psicológicos del testimonio}

La declaración testimonial supone que el testigo conoce de la ocurrencia del hecho materia de probanza o de las circunstancias precedentes, o de las que acompañaron o siguieron a su ocurrencia, o bien tiene un conocimiento indirecto del mismo.

En el caso de un evento delictivo, el nuevo Código Procesal Penal expresa que la «declaración del testigo versa sobre lo percibido en relación con los hechos delictuosos, y con sus circunstancias que son materia de investigación. Si su conocimiento es indirecto, debe señalar el momento, lugar y medio por los cuales lo obtuvo.

No se le admite al testigo expresar los conceptos u opiniones que personalmente tenga sobre los hechos y responsabilidades" (Art. 197 ${ }^{\circ}$.

El testimonio tiene su fuente en una fecha pasada, con el conocimiento del hecho, y su punto de llegada en el momento de la declaración, lo que significa que tiene dos fases generales: una de conocimiento o cognoscitiva (actus de praesentia), y otra fase declarativa (declaratio de scientia). Por ello, en forma específica, como decía Emilio Mira, el "testimonio de una persona acerca de un acontecimiento cualquiera, depende básicamente de cinco factores: a) del modo cómo ha percibido dicho acontecimiento; b) del modo cómo lo ha conservado en su memoria; c) del modo cómo es capaz de evocarlo; d) del modo cómo quiere expresarlo; e) del modo cómo puede expresarlo». ${ }^{19}$

\subsection{Fuente del conocimiento materia del testimonio}

De acuerdo a las normas procesales civiles como penales, entre otras, el acto de la declaración testimonial se cumple y agota con la sola transmisión del conocimiento de un hecho por el testigo. Por ello, general-

19 Kurt Schneider. Op. cit. 
mente la doctrina y legislación procesal sobre este tema, se concentran en la fase en que el testigo transmite el conocimiento por él adquirido, o sea en la etapa declarativa que puede estar temporalmente cercana o lejana al momento en que fue conocido el hecho. Esto significa que descuida el momento o etapa en que el testigo recepciona el hecho, o sea del punto de partida del «iter" del testimonio.

En todo acto testimonial se sobreentiende que el testigo tuvo un conocimiento, generalmente directo o indirecto de algo que es útil declarar en el proceso judicial. Pero este saber o conocimiento acerca de algo que es materia de litis, supone necesariamente la secuencia de una serie de procesos y condiciones intrapsíquicas especiales.

En primer lugar, la persona que en un futuro actuará como testigo de hechos, toma conocimiento de lo que va a declarar mediante determinados procesos perceptuales, generalmente de tipo visual o auditivo, a veces olfatorio y/o táctil. Esto, en términos generales, indica un proceso de percepción o sensoperceptual. En segundo lugar, el tipo de percepción que interesa en el testimonio, requiere algún grado suficiente de atención prestada al hecho materia de la declaración, y esto nos plantea analizar las particularidades de este fenómeno y su grado de concentración, para que se haya podido grabar el hecho percibido. En tercer lugar, el hecho o situación percibido con algún grado de atención, requiere alguna forma de almacenamiento en la memoria del futuro testigo, un grado suficiente de procesos mnémicos que permitan posteriormente su evocación o recuerdo en el acto testimonial. Asimismo interesa conocer el fenómeno del olvido, que es un proceso que ocurre en toda experiencia vivida, en mayor o menor intensidad. Otro aspecto es cómo se comunica lo evocado por el testigo, cuál es el grado de su capacidad verbal, su habilidad comunicativa y deficiencias; $y$, finalmente, no podemos descuidar los aspectos actitudinales en el testigo, cuál es su actitud frente a las partes o los hechos sobre los que declara, y que puede influir en algún sentido, en su participación como testigo.

Por todo lo anterior estamos de acuerdo con Ettore Dosi cuando afirma que «es necesario también reconocer que es fruto de un grave error analizar el testimonio atendiendo sólo al momento declarativo, el cual, según ya se ha señalado, termina por representar solamente el punto de llegada de la experiencia vivida por el testigo», ${ }^{20}$ cuando real- 
mente para que se produzca la fase del conocimiento del hecho que será materia de declaración testimonial, el testigo ha debido poner en juego una serie de procesos psicológicos concatenados, de los que realmente depende la validez del testimonio, y que son los siguientes:

\subsection{Procesos sensoriales y perceptuales}

El ser humano en la vida cotidiana se pone en contacto con el mundo externo e interno mediante los diversos órganos de los sentidos, de tal modo como dice el neuropsicólogo soviético A. Luria (1975) las «sensaciones constituyen la fuente principal de nuestros conocimientos acerca del mundo exterior y de nuestro propio cuerpo. Ellas son los canales básicos por los que la información sobre los fenómenos del mundo exterior y en cuanto al estado del organismo llega al cerebro, dándole al hombre la posibilidad de orientarse en el medio circundante y con respecto al propio cuerpo. Si dichos conductos estuvieran cerrados y los órganos de los sentidos no llevasen la información necesaria, no sería posible ninguna vida concientem. ${ }^{21}$ En sentido similar se refieren Peter Lindsay y Donald Norman (1977) cuando afirman que los sentidos: ver, oir, tocar, gustar, sentir, son las ventanas al mundo, que alimentan al cerebro con la información respecto al entorno. ${ }^{22}$

\subsubsection{Procesos perceptuales}

Toda la información sensorial, no llega a tener significación, ya que el «ojo registra los patrones de luz y oscuridad, pero no «ve» a un peatón que cruza la calle. El tímpano vibra de manera particular ante ciertos estímulos, pero no "oye» una sinfonía. Ver y escuchar patrones significativos en ese desorden que es la información sensorial es lo que nosotros llamamos percepción", de acuerdo a lo que plantea Charles Morris. ${ }^{23}$ En otros términos, la percepción es un proceso consistente en crear patrones significativos a partir de la información sensorial en

21 Florencio Mixán. La prueba en el procedimiento penal. Lima, Ediciones Jurídicas, 1991.

22 Peter Lindsay y Donald Norman. Introducción a la psicología cognitiva. Madrid, Ed. Tecnos, 1983.

23 Charles Morris. Op. cit. 
bruto, y es precisamente el cerebro el que interpreta el flujo de información tan compleja que procede de los sentidos, y crea experiencias perceptuales que van más allá de lo que se capta mediante los sentidos.

A. Smirnov y otros, dicen que la «percepción se completa y perfecciona, en un grado mayor o menor, con los conocimientos que se tienen de la experiencia anterior. A consecuencia de esto, el hombre percibe los estímulos que actúan sobre él como objetos determinados de la realidad: árboles, casas, otras personas, etc. La percepción de algo, como objeto o fenómeno determinado de la realidad, sería imposible sin el apoyo en la experiencia pasadam. ${ }^{24}$

Los gestaltistas que investigaron sobre la percepción señalaron algunos principios sobre la organización perceptual:

a. Figura y fondo: en el proceso perceptual somos capaces de distinguir la figura del fondo contra el cual aparece. Esta distinción se aplica a todos los sentidos y no sólo a la vista.

b. El cierre: es otro principio de la organización perceptual, que se refiere a la inclinación a pasar por alto lo incompleto en la información sensorial, y a percibir un objeto entero, aún cuando realmente no exista en forma completa.

c. El principio de proximidad: cuando los objetos están cerca uno de otro, tendemos a percibirlos juntos y no por separado.

d. La semejanza: es otro principio de agrupamiento. Los objetos que son de color, tamaño o forma parecida, suelen percibirse como parte de un sólo patrón.

Asimismo, los fenómenos perceptuales tienen mucha relación con las Características del observador, sobre todo dependen mucho de la experiencia personal y del aprendizaje, como los siguientes:

a) Motivación. Generalmente las necesidades y deseos del sujeto influyen profundamente en sus percepciones. Por ejemplo, las personas que tienen una necesidad, tienden a percibir algo que piensan que les va a satisfacer.

b) Expectativas. Si sabemos de antemano lo que hemos de percibir, ello influirá en nuestra percepción. 
c) Estilo cognoscitivo. A medida que maduramos adquirimos un método general de afrontar el ambiente.

d) Antecedentes y formación cultural. El idioma que hablamos y otras diferencias culturales pueden influir en la percepción del ambiente.

\subsubsection{Alteraciones de la percepción}

Si tomamos en cuenta los rasgos característicos de la percepción, veremos que muchos aspectos de los perceptos, sean visuales, auditivos, olfatorios, gustativos, entre los principales, contienen una importante influencia del individuo, debido a su experiencia y otras características singulares.

Al margen de tales consideraciones, que pueden favorecer el hecho de tener percepciones que no reflejen necesariamente las características objetivas de la realidad, podemos considerar dos alteraciones cualitativas típicas, una de carácter que podemos llamar a veces "normal" y otra que se presenta muchas veces en casos de patología mental, estas son las ilusiones y las alucinaciones respectivamente.

A. Ilusiones perceptuales. En las ilusiones se da una interpretación equivocada de la percepción de una experiencia sensorial externa, y se pueden manifestar a nivel visual, auditivo u otro ámbito sensorial. Al respecto Lindsay y Norman dicen que las "cosas no siempre aparecen como son realmente. Lo que vemos u oimos no siempre es lo que es. El sistema perceptivo comete errores con frecuencia. A veces vemos ilusiones, a veces se requiere tiempo para que el sistema perceptivo se recupere de una estimulación prolongadan..$^{25}$

Muchas ilusiones visuales se deben a señales que proporcionan información errónea sobre la distancia o la profundidad. Por ejemplo, ¿a qué se debe que el sol o la luna dan la impresión de ser más grandes cuando están cerca del horizonte que en el cenit?. Hoy la mayoría de investigadores explican el fenómeno recurriendo a la teoría de la distancia aparente de Kaufman y Rock (1962). En el campo de las ilusiones se distinguen diversas manifestaciones de tal alteración:

a. Ilusiones fantásticas o pareidólicas. Generadas por la fantasía sobre la base de un estímulo real sensorial, por ejemplo ver determinadas figuras en una mancha de tinta.

25 Peter Lindsay y Donald Norman. Op. cit. 
b. Ilusiones por inatención. Alteraciones de la percepción debidas a la distracción del sujeto.

c. Ilusiones afectivas o catatímicas. Son alteraciones motivadas por situaciones emotivas. Por ejemplo una persona temerosa puede ver en la oscuridad un "fantasma» cuando se trata realmente de la sombra de un árbol.

d. Ilusiones oníricas. Por una disminución de la conciencia, en los estados crepusculares y delirios oníricos.

Dadas las características de la percepción y la posibilidad de errores diversos, así como de procesos de ilusión muy variados, la declaración testimonial sobre un evento percibido, puede no siempre reproducir fielmente el hecho, y como consecuencia constituir una información sujeta a duda o no ser confiable.

B. Alucinaciones. Estos trastornos se pueden dar en los ámbitos visual, auditivo u otro tipo de percepción, y como dicen Alfred Freeedman y otros, «las alucinaciones son percepciones sensoriales falsas que no van asociadas a estímulos externos reales». ${ }^{26}$

La alucinación puede ser motivada o inducida por factores emocionales o por factores orgánicos como las debidas al consumo de drogas y el alcohol o estados psicóticos, hasta estados de somnolencia. Asimismo existen diversos tipos de alucinación, como los siguientes:

a. Alucinaciones hipnagógicas. Que son percepciones sensoriales falsas que se producen en la transición de la vigilia al sueño. Si la alucinación se produce inmediatamente antes de despertar plenamente se denomina hipnopómpica.

b. Alucinación auditiva. Percepción auditiva falsa, que puede ser desde ruidos, hasta voces de carácter amenazantes o insultantes.

c. Alucinación visual. Percepción visual falsa, menos frecuentes que las auditivas, pueden ser:

- Fotopsias, como lucecillas y colores de forma indefinida.

- Imágenes visuales aterradoras como en el delirium tremens.

- Alucinaciones liliputienses o percepción de objetos como si estuviesen reducidos de tamaño. Es frecuente ver por ejemplo ani-

26 Alfred Freedman y otros. Compendio de psiquiatría. Barcelona, Salvat Editores, 1978. 
males pequeños de color o "microzoopsias», en ciertos delirios tóxicos.

- Alucinaciones gulliverianos, en la que se perciben imágenes gigantescas, en intoxicaciones exógenas y en esquizofrenias.

d. Alucinación olfatoria. Falsa percepción de olores, generalmente de carácter desagradable, se da en estados esquizofrénicos y en lesiones del lóbulo temporal.

e. Alucinación gustatoria. Percepción falsa del gusto, aunque es menos frecuente.

f. Alucinación táctil o háptica. Falsa percepción del tacto, como la sensación de gusanos sobre la piel.

g. Alucinación cinestésica. Falsa percepción de movimiento o sensación, como por ejemplo de un miembro amputado (miembro fantasma).

Estas alucinaciones, si fueran la fuente de los datos de un testigo, obviamente distorsionarán la objetividad de su declaración que se sustenta en falsos perceptos.

\subsection{Procesos atencionales}

Los estudios sobre la atención se iniciaron conjuntamente con el nacimiento de la psicología científica, sin embargo este interés decayó por un tiempo prolongado, desde inicios del siglo XX, por casi cinco décadas. Posteriormente con el surgimiento de las tendencias cognoscitivas en la psicología, renace el interés por su estudio, sobre todo con el trabajo de Broadbent: Perception and Communication (1958).

Según E. R. Hilgard ${ }^{27}$, se denomina atención al proceso de concentración perceptual ante determinados estímulos. «Por medio de este proceso de atención nos concentramos en los estímulos seleccionados y resistimos a los que nos distraen". Además, dentro del proceso de la atención existen dos grupos de factores muy importantes:

27 Ernest Hilgard. Introducción a la psicología. Tomo I, Madrid, Ed. Morata, $4^{\text {a }}$. Ed., 1973. 
2.3.1 Estructura de los estímulos externos o del campo externo

Son factores derivados de los estímulos que el sujeto percibe, y ellos determinan la orientación, el volumen y la estabilidad de la atención. En nuestra vida cotidiana existen multitud de estímulos ante nosotros, y seleccionamos alguno de ellos para prestarle atención, en función a diversas condiciones que favorecen su selección, tales como:

- Estímulo de mayor tamaño

- Mayor intensidad del estímulo (fuerza)

- Movimiento del estímulo

- Repetición frecuente

- Estímulo más vívido

- Contraste del estímulo

- Color llamativo

- Novedad del estímulo, etc.

2.3.2. Estructura del campo interno o factores concernientes a la actividad del propio sujeto

Se consideran dentro de este campo, una serie de condiciones individuales, de la persona actora del proceso atencional, como los siguientes:

- Intereses

- Necesidades

- Estados emocionales

La atención parece tener una naturaleza fundamentalmente selectiva. Por ello A.M. Treisman (1969) la define como «el aspecto selectivo de la percepción" (Cit. por Seoane). ${ }^{28}$ En el caso de un proceso judicial, cuando el juez cita a un testigo, para que declare sobre un hecho ocurrido en un período anterior, se supone tácitamente que la persona ha prestado atención adecuada al hecho o experiencia sobre el que va a declarar, pero esto no siempre es así, porque esta persona que estuvo realmente presente en el evento, pero si no prestó la atención mínima

28 I. Delclaux y J. Seoane. Psicología cognitiva y procesamiento de la información. Madrid, Ed. Pirámide, 1982. 
requerida, es improbable que pueda retener datos significativos en su memoria de largo plazo, aún más, si consideramos las distorsiones que también sufre la memoria humana, como lo veremos más adelante.

\subsection{La memoria}

Es, además de los anteriores procesos, uno de los principales sistemas cognoscitivos humanos que es importante conocer, para sopesar la validez de toda prueba testimonial. Según A. Luria (1975), «entendemos por memoria la impresión (grabado), retención y reproducción de las huellas de la experiencia anterior ${ }^{29}$.

Los estudios actuales sobre la memoria, tienden a seguir un modelo explicativo y comprensivo que difiere y supera a las orientaciones asociacionistas de los primeros cincuenta años del siglo XX, planteando los siguientes criterios:

a) En primer lugar, el sujeto que adquiere datos de su entorno, es un procesador activo de información, no es un simple receptor, sino que lo elabora en base a los datos y conocimientos que ya posee. En este caso se enfatiza en los procesos internos frente a los estímulos del viejo paradigma.

b) En segundo lugar, la idea del sujeto como procesador de información, da lugar a que las relaciones asociativas entre los datos que adquiere, no pueden ser solamente asociaciones E-R (estímulo-respuesta) sin ningún contenido. El nuevo modelo no rechaza la asociación, pero la completa al anotar que dicha asociación es de contenido.

c) Dentro de este contexto los modelos estructurales, a diferencia de los asociacionistas, parten del criterio que desde que el sujeto percibe un estímulo hasta que lo integra en su bagaje cognitivo, la información pasa por diversas estructuras de almacenamiento, cada una de las cuales abarca una determinada elaboración de dicha información.

Como dicen Lindsay y Norman (1977), el «sistema de la memoria humana es capaz de una rica variedad de operaciones. En un extremo,

29 A.R. Atención y memoria. Barcelona, Ed. Fontanella, 1979. 
mantiene un registro muy detallado de las imágenes sensoriales el tiempo suficiente para permitir la identificación y clasificación de las visiones, sonidos, olores, sabores y sensaciones. En el otro extremo, la memoria registra nuestras experiencias para su uso durante toda nuestra vida». ${ }^{30}$

Ya hemos visto, que en un primer momento, los estímulos físicos que proceden del medio son recepcionados por diferentes procesos neurosensoriales (visual, olfativo, auditivo, etc.), y son mantenidos por breve tiempo en unas memorias sensoriales con el fin de que se produzcan procesos de extracción de características y reconocimiento de formas. Estos procesos lo que hacen es recoger la información pertinente de tales memorias sensoriales y la pasan a otra estructura transitoria de la memoria, la memoria a corto plazo. Otros mecanismos pondrán en relación la información registrada y mantenida en la memoria a corto plazo con viejos contenidos antes adquiridos, "produciendo así la transferencia a la llamada memoria a largo plazo de la nueva información, que quedaría integrada, de modo permanente, en nuestro bagaje cognitivo o sistema de conocimiento". ${ }^{31}$

\subsubsection{Memoria sensorial}

Si al leer este artículo, deja de hacerlo, y se dedica a observar el lugar donde se encuentra, advertirá que con cada mirada, que puede durar fracción de segundos, captará gran cantidad de datos o información visual: como formas, colores, texturas, sombras, brillantez, etc. Al mismo tiempo puede percibir sonidos, olores y otros datos sensoriales. Sin embargo la información que registra, permanece un breve lapso y luego se procesa o bien se pierde.

La "memoria" sensorial es sólo el registro o persistencia del estímulo, y no supone ningún tipo de elaboración o transformación del mismo. Es un registro textual de lo que nos llega. El almacenamiento de información sensorial (AIS) o registro sensorial, mantiene el estímulo por más tiempo que su presencia física, para facilitar que el sistema de reconocimiento de formas y extracción de características pueda actuar sobre el mismo. Debido a que es un simple almacenamiento fugaz, 
diversos estudiosos del procesamiento de la información dudan en llamarla memoria sensorial como lo hacen otros.

Con el registro sensorial visual se captan muchos datos en cada momento y si tratamos de retener la imagen visual o "ícono", veremos que ésta se desvanece pronto, en décimas de segundos. Pero en la vida cotidiana, nueva información visual sigue llegando constantemente y «borra» o sustituye a la anterior. Un estudio psicológico ha comprobado que, en condiciones normales de visualización, esta información se borra del registro sensorial en un cuarto de segundo aproximadamente y es reemplazada por otra. Como existen diversos estímulos sensoriales, se plantea que cada modalidad sensorial tendría su respectiva memoria, existiendo entonces una memoria visual o icónica.

El registro auditivo se desvanece con menor lentitud que la visual. El equivalente auditivo del ícono (imagen) es el eco, que tiende a durar varios segundos, lo cual es positivo dada la característica del habla. En caso contrario no podríamos distinguir sutilezas de significación, en las diversas formas de entonación que se emplea en la vida cotidiana. El estímulo auditivo es registrado por el sistema neurosensorial auditivo y luego almacenado por breve tiempo en la memoria ecoica o auditiva.

En general, la memoria sensorial es de muy breve duración, después de la cual se pierde o se recodifica. Aproximadamente dura de uno a cinco décimas de segundo.

\subsubsection{Memoria a corto plazo (MCP)}

Esta memoria "es aquella en lo que estamos pensando en un momento determinado». Cuando estamos oyendo una conversación o parte de una canción, cuando nos damos cuenta de un adormecimiento de las manos o sentimos un dolor en los ojos, estamos usando en todos estos casos la memoria a corto plazo para retener la información, en un momento determinado, y pensar en lo que nos está llegando de los registros sensoriales. De este modo, este tipo de memoria realiza dos actividades centrales: guarda brevemente nuevos datos y actúa sobre ellos. Por ello a veces se le denomina también «memoria funcional».

La retención del contenido que almacena este tipo de memoria es breve, ya que generalmente el «material de la memoria a corto plazo desaparece en un lapso de 15 a 20 segundos, a menos que se repase o 
practique (Klatsky, 1980; Reed, 1982)", esto es, mediante un esfuerzo voluntario, repitiendo mentalmente (repetición de mantenimiento) el material una y otra vez, se le puede retener en esta memoria durante un tiempo.

La cantidad de la información, en determinado momento, tiene un límite en la MCP. Puede incluir de cinco a diez trozos de información simultáneamente. Este material es guardado y codificado de diversas formas, algunos se guardan acústicamente, también parte del material se guarda en forma visual, mientras que otra información se retiene en función de su significado. Aunque parece que «la capacidad de la memoria a corto plazo es mayor en la codificación visual que en la codificación acústica (Reed, 1982)». ${ }^{32}$

En resumen, podemos anotar que tanto al AIS como la MCP son memorias transitorias, por sus características ya anotadas.

\subsubsection{Memoria a largo plazo (MLP)}

Abarca a todo el bagaje cognitivo o la estructura del conocimiento del sujeto. En otros términos viene a ser «el almacén de toda la información que adquirimos a lo largo de la vida: el conjunto de conocimientos que posee un sujeto». ${ }^{33} \mathrm{El}$ sistema de MLP es el más importante y complejo. Todas las cosas que se retienen durante más de unos minutos tienen que almacenarse en la memoria a largo plazo, y parece no haber límite práctico en la capacidad de este tipo de memoria. Además, en las últimas décadas se tiende a distinguir, siguiendo a E. Tulving (1972), dos variedades de memoria a largo plazo:

A. Memoria semántica. Es la memoria a largo plazo que representa el conocimiento de la persona, haciendo alusión con ello a la estructura y organización de toda la información y conocimientos que adquirió sobre sí mismo, el entorno y el mundo social. Esta memoria hace referencia al conocimiento que el sujeto va estructurando y organizando a lo largo de su vida, y como dice Charles Morris (1985), se asemeja mucho a un diccionario o enciclopedia. En otros términos es la información caracterizada por las definiciones que tienen

32 Charles Morris. Op. cit.

33 I. Delclaux y J. Seoane. Op. cit. 
en sus memorias las personas. Un ejemplo de ello es la noción de justicia, el concepto de lo bueno, de altura, amor, mundo, etc.

B. Memoria episódica. Es la memoria a largo plazo más personal y específica, que tiene significado individual para cada persona y se asemeja a un diario. Incluye por ejemplo, fecha de nacimiento, el día de graduación, lo que se comió en la víspera, etc. Es pues la información sobre eventos particulares que se han vivido. Lindsay y Norman, afirman que «la memoria semántica generalmente se desarrolla a partir de la información almacenada en la memoria episódica». ${ }^{34}$

\subsection{El olvido de la información}

El olvido es un proceso normal e incluso necesario y sano por el que se pierde temporal o para siempre la posibilidad de evocar la información que constantemente recepciona el sujeto. Asimismo el olvido de la MCP depende de varias condiciones, y considera las siguientes teorías:

La teoría del decaimiento o del deterioro temporal. Conforme a esta teoría, el paso del tiempo hará que la fuerza de la memoria merme, con lo cual se dificultará la retención del material. En este caso se postula el paso del tiempo como condición suficiente para que ocurra el olvido, sin embargo otros estudiosos plantean otras explicaciones también plausibles.

La teoría de la interferencia. Considera que la información se confunde con otra información o bien es desplazada por ella, de modo que resulta más difícil de recordar. Esta interferencia proviene de dos fuentes:

a) La inhibición retroactiva, cuando el nuevo material puede entorpecer al material ya presente en la memoria a corto plazo.

b) La inhibición proactiva, cuando el material nuevo presente en la MCP puede interferir en la información de entrada.

Sin embargo el proceso del olvido no es un simple efecto del paso del tiempo o la interferencia de otros contenidos, sino también tiene carácter selectivo. Como dice Petrovski (1976) «Un material de impor-

34 Peter Lindsay y Donald Norman. Op. cit. 
tancia estable [...] relacionado a las necesidades de la persona, a sus intereses profundos [...], se olvida con más lentitud». ${ }^{35}$

También pueden ocurrir alteraciones patológicas de la evocación, debidas a causas diversas y manifestarse también en varias formas como las siguientes:

\subsubsection{Amnesia}

Es la incapacidad total o parcial de recordar experiencias pasadas. Esta alteración puede tener causas emocionales u orgánico-cerebrales. Existen clasificaciones diversas de la amnesia ${ }^{36}$, como las siguientes:

A. Amnesia anterógrada. También llamada de fijación, es el transtorno mnémico caracterizado por la incapacidad para la fijación de nuevos datos o engramas, de tal modo que no se recuerda los hechos recientes, a partir del fenómeno que originó la perturbación, pero pueden recordarse sucesos anteriores. Se presenta por ejemplo en el síndrome de Korsakov.

B. Amnesia retrógrada. Pérdida de la memoria que se extiende hacia atrás y cubre un período variable anterior al inicio de la amnesia. Por ejemplo a causa de una conmoción cerebral, no se puede evocar la vida anterior.

C. Amnesia lacunar. Se olvida sólo determinados trozos del pasado, pudiéndose evocar los anteriores y posteriores a dicho período.

\subsubsection{Paramnesia}

Es una distorsión del recuerdo, asociada generalmente con la inclusión de detalles falsos o relaciones temporales equivocadas. Se pueden distinguir varias formas:

A. La fabulación o confabulación. Es una alteración que consiste en llenar vacíos mnémicos con evocaciones imaginarias. Se presenta sobre todo en la psicosis de Korsakov. 
B. Fausse reconnaissance ó «Falso reconocimiento». Es el sentimiento de certeza de estar evocando correctamente algo que es inexacto de manera patente. Este tipo de alteración es frecuente también en la psicosis de Korsakov, en el que la paramnesia incorpora la fabulación y la falsificación retrospectiva.

C. Déjá vu. Ilusión de reconocimiento visual, en la que se considera de manera incorrecta una situación como una repetición de un recuerdo anterior. Ocurre con frecuencia en ciertos estados psiconeuróticos y ocasionalmente en el aura de una crisis epiléptica.

D. Jamais vu. Es un falso sentimiento de extrañeza ante una situación real que se ha experimentado, es un desconocimiento de lo conocido.

E. Déjá entendu. «Ilusión de un reconocimiento auditivo», «en el que un comentario que nunca se había escuchado antes se considera incorrectamente como una repetición de una conversación anteriorn.

\subsubsection{Hipermnesia}

Grado exagerado de retención y recuerdo. Se observan en algunos casos prodigios, también en la neurosis obsesivo compulsiva, la paranoia y la manía, así como en algunos deficientes mentales en ciertos contenidos especiales.

\subsection{Evocación y distorsión de la información}

El material almacenado, sobre todo en la memoria a largo plazo, no está presente en todo momento en la conciencia, pero puede ser recordado o evocado, pero también además del olvido puede sufrir la distorsión de tales contenidos mnémicos.

\subsubsection{La evocación}

También se refiere al recuerdo de lo almacenado en nuestra memoria a largo plazo, presenta diferencias en función del tipo de memoria. Al respecto Peter Lindsay y Donald Norman consideran que los datos de la memoria semántica son más accesibles, sin aparente esfuerzo o búsqueda de la información; sin embargo consideran que a menudo es 
difícil recordar la información episódica. Por ejemplo: cuáles fueron exactamente los acontecimientos que ocurrieron el mes pasado, o lo que se comió en la cena de hace una semana.

Precisamente la declaración testimonial, generalmente está referida a datos que conciernen a la memoria episódica, lo que debe llevarnos a tener cautela y no confiar totalmente en la certeza del «vívido y claro recuerdo" que expresan muchos testigos al dar su declaración, aún tratándose de personas serias y honestas.

Fig. Procesos mnémicos

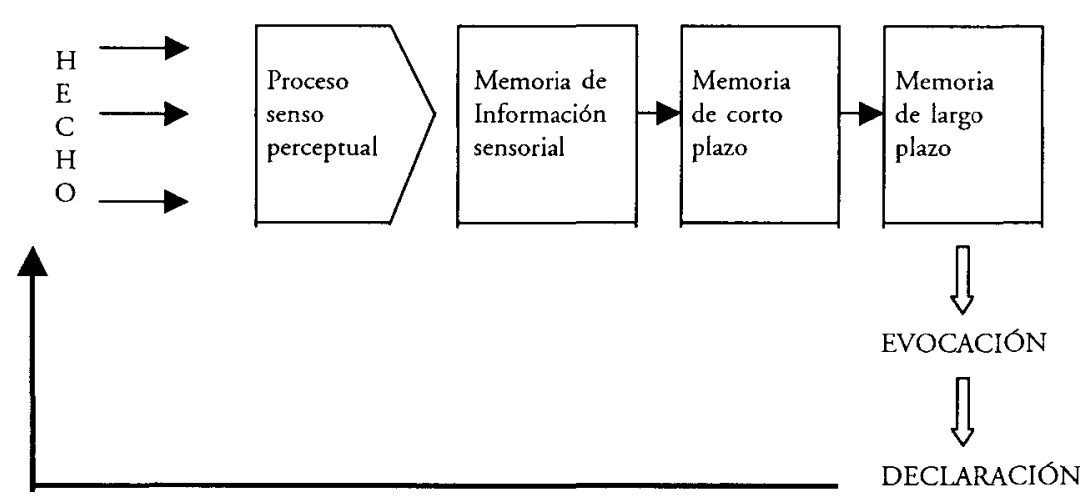

En suma, para poder evocar hechos acaecidos anteriormente, cuya información tenemos almacenada en nuestra MLP, la secuencia de tales procesos interconectados debe ocurrir sin alteraciones importantes, desde:

1) La recepción de información mediante procesos senso-perceptuales y atencionales,

2) Almacenamiento de la información a través de procesos de memoria sensorial, MCP y MLP,

3) La recuperación (evocación) de los datos y su comunicación o transmisión.

En esta secuencia se interconectan la mayor o menor credibilidad del contenido del testimonio y la mayor o menor frabilidad que se puede tener del testigo. 


\subsubsection{Distorsión de la memoria y el testimonio}

Hemos visto diversos procesos cognitivos, que tienen importancia para recepcionar y almacenar determinada información, que se inicia mediante procesos perceptuales, sobre todo visuales y auditivos o también de tipo táctil, olfatorio o gustativo, o mediante una combinación de ellos; cuya selectividad perceptual depende del nivel de atención que se preste al hecho, ya que no obstante haber estado presente en el momento en que ocurrió el evento materia de testimonio, si nuestra atención se orientó a otros estímulos, dicho evento no entrará en los almacenes mnémicos. En el supuesto positivo que se haya prestado atención y haya entrado en la memoria sensorial y luego en la de corto plazo, pero si no se realizó un proceso complementario de repetición, el hecho registrado inicialmente en los primeros niveles de nuestra memoria, será olvidado y no entrará en la memoria a largo plazo.

Si se hubiera almacenado la información en nuestra memoria a largo plazo, estos datos formarán parte de nuestra memoria episódica, que es la más difícil de retener. Además, por los diversos procesos internos, la experiencia y los datos que constantemente se acumulan, el material episódico puede sufrir distorsiones de distinta característica, lo que atenta contra la credibilidad total de una declaración testimonial.

Además, el testigo es una persona cuya frabilidad es muy variada, pudiendo hallarse personas veraces hasta algunas otras con diverso grado de mendacidad, y si además se altera la credibilidad del contenido, el testimonio se hace más aleatorio e inseguro; por ello Miguel Herrera decía que la «fidelidad del testigo no es suficiente garantía de absoluta certeza en sus dichos, otros múltiples factores de orden subconciente, de niveles mentales e imaginativos, vician declaraciones testimoniales de elevada moralidad y buena fe ${ }^{37}$. 


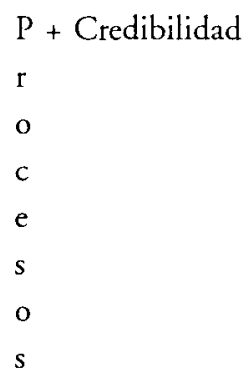

- CONDICIONES INDIVIDUALES +

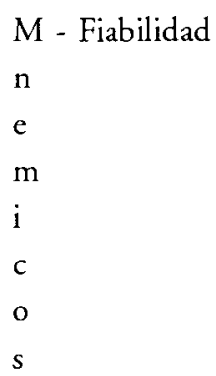

Actualmente, Charles Morris (1985) dice que la «confianza en los testigos oculares acaso sea injustificada». No obstante que pueden aportar información valiosa, «los estudios revelan sin lugar a dudas que los que dicen «se muy bien lo que vi» a menudo quieren decir «se muy bien lo que pienso haber visto». Y pueden equivocarse». ${ }^{38}$

Una psicóloga, experta en estos estudios, Elizabeth Loftus (1983), realizó el siguiente experimento: dos mujeres entraron a un terminal de autobuses y dejaron sus cosas en una banca, mientras verificaban la hora de salida del autobús. Un hombre llega y busca en las cosas y guarda algo debajo de su abrigo, alejándose luego. Una de las mujeres regresa y al revisar su maleta, exclama: «Me han robado la grabadora». Cuando los investigadores del seguro interrogaron a los testigos que estaban allí cerca, éstos confirmaron el hecho. Varios de ellos dieron una descripción pormenorizada de la grabadora faltante, indicando detalles como color, tamaño y forma. Pero realmente nunca hubo una grabadora en el equipaje. El hombre y la mujer de los hechos eran ayudantes de la psicóloga que estudiaba la credibilidad del testimonio de los testigos oculares. 
José Mira y Margarita Diges (1986), en un trabajo sobre el tema presentan casos de error judicial, debido a testimonios errados, que condujeron a proceso penal a personas inocentes, cuya apariencia física era parecida a los autores del hecho delictivo, lo que probablemente influyó para que el "reconocimiento" que hicieron los testigos fuese equivocado. Estos autores afirman que «los testigos que identifican erróneamente a un sospechoso suponen que todo ocurrió de una determinada forma, atribuyen responsabilidades en base a ideas estereotipadas, rellenan lagunas de sus recuerdos conforme imaginan todo lo que pudo suceder [...]. Lo que sucede a nuestro alrededor lo solemos interpretar conforme a nuestras expectativas, motivos, necesidades, estereotipos y sentimientos», ${ }^{39}$ de tal manera que los equívocos típicos de los testigos se pueden explicar en función a este modelo de funcionamiento de la memoria, en el que no sólo se altera la información en el momento de su codificación, sino también al momento de su evocación y comunicación. En otros términos, la persona no graba como un sujeto pasivo la escimulación ambiental que recibe; sino que también impone una estructura particular a los eventos que recepciona, y en cada ocasión que requiera su evocación pueden ocurrir modificaciones incluso de una vez para otra.

Estos estudios y otros datos respecto a la memoria humana, nos indican que ésta presenta procesos de distorsión, fenómeno del que no escapa el testimonio de un testigo en un proceso judicial.

\section{El interrogatorio judicial del testigo}

La evocación de datos relativos a un hecho, sobre el que versa la declaración de un testigo, puede afectarse en algo por la forma de interrogatorio judicial. Según Mira y Diges, la «forma de las preguntas, cómo se formulan o el modo de llevar a cabo el interrogatorio de los testigos, constituye un bloque aparte de investigaciones y trabajos sobre el efecto del lenguaje en el proceso legal». ${ }^{40}$ Asimismo la recepción de la

39 José Mira y Margarita Diges. "Procesos intervinientes en la evidencia de testigos». En F. Jiménez y M. Clemente, Psicología social y sistema penal. Madrid, Alianza Editorial, 1986.

40 José Mira y Margarita Diges. Op. ctt. 
declaración testimonial en nuestra práctica judicial es variada según el tipo de proceso, bien sea penal, civil o de otra área jurídica.

\subsection{Interrogatorio del testigo en el fuero penal}

Según el artículo $145^{\circ}$ del Código de Procedimientos Penales de 1940, luego que el testigo haya dado sus referencias personales, el Juez le invitará a que exprese ordenadamente los hechos que considere pertinentes, procurando, por medio de preguntas oportunas y observaciones precisas que la declaración sea completa y que de explicación de las afirmaciones o negaciones que haga.

Cuando el procesado concurre con su defensor a la declaración de un testigo, podrá solicitar al Juez penal, que éste haga determinadas preguntas. El Juez podrá acceder o negarse (Art. $158^{\circ}$ C.P.P., 40). En todos los casos, el testigo declarante debe responder oralmente, sin auxiliarse de escrito ni documento alguno.

Cuando se trate que el testigo reconozca a una persona o cosa, deberá describirla previamente, y después le será presentada para su reconocimiento (Art. $146^{\circ}$ C.P.P., 40).

Los testigos podrán ser citados para que declaren nuevamente en la audiencia (Art. $248^{\circ}$ C.P.P., 40).

El Código Procesal Penal de 1991, que quedó pendiente de entrar en vigencia, estipula en cuanto al interrogatorio del testigo, similares recomendaciones, con la diferencia que en este caso, es el Fiscal como titular de la acción penal el que debe interrogar conforme al artículo $202^{\circ}$ del C.P.P. 91.

Si se trata de testigo mudo o sordo, o bien sordomudo, el interrogatorio será en forma escrita, debiéndose emitir las respuestas también en la misma forma, salvo el sordo que contestará oralmente.

En los casos que el testigo sordo no sepa leer o el mudo no sepa escribir, intervendrá en la diligencia una persona hábil, bajo juramento, para que entiendan y se hagan entender.

En estos casos existen una serie de limitaciones a ser tomadas en cuenta, para valorar en qué medida los limitados sensoriales que deben redactar sus respuestas, o mas aún en el caso de limitados sensoriales carentes de la capacidad de lectura o escritura, cuya comunicación será a través de un intermediario, puedan ser considerados testigos mediante un procedimiento de comunicación en la que no existen certeza y 
claridad de los mismos, unido a otras limitaciones respecto a los procesos psicológicos que intervienen en la recepción, almacenamiento y evocación de los datos que son materia del proceso judicial penal.

Según esta práctica, donde la ley otorga al Juez y al Fiscal la potestad de realizar el interrogatorio del testigo, podemos vislumbrar que muchas veces la eficacia de esta diligencia depende de una serie de condiciones, una de las cuales reposa en la capacidad, experiencia o habilidad del interrogador. Al respecto, el problema más genérico en esta práctica, es que el Juez recurre a un esquema generalmente similar en todos los casos y con casi todos los testigos, lo que evidentemente no debería ser, sino que en cada acto testimonial se debería adoptar una estrategia adecuada en función de las características diferenciales del testigo, y también de los procesos psíquicos que se trata de poner en marcha con la pregunta. Esto significa que debe tenerse, por parte del interrogador principal, Juez y Fiscal, un mínimo de conocimientos de los procesos psicológicos inmersos en la testificación, como la percepción, atención, memoria, prejuicios y capacidad de verbalizar sus respuestas por parte del testigo, y considerar también algunos de los siguientes puntos :

- En general es importante ser claros en la formulación de las preguntas, esto es empleando términos sencillos y entendibles, de tal modo que el interrogado comprenda lo que se le pregunta, porque si el testigo recepciona un significado diferente en la interrogante del Juez, es probable que la respuesta no corresponda a la pregunta. Este es un tópico importante de comunicación que el Juez debe tener en cuenta, y como dice Florencio Mixán, la falta de claridad de las preguntas pueden ser por: a) construcción gramatical defectuosa, b) que contenga expresiones desconocidas para el interrogado, y c) que contenga un desorden gramatical y conceptual. ${ }^{41}$

- Debe evitarse el empleo de preguntas ambiguas, que pueden ser comprendidas en varios sentidos por el testigo interrogado, que obviamente confunden y atentan contra una objetiva declaración testimonial.

- Otro aspecto es la estrategia de conducción del interrogatorio. Al respecto decía Emilio Mira, que no se debe seguir un interrogatorio 
centrípeto o sobre el hecho problema en forma directa, que puede bloquear y propiciar que el testigo se inhiba o defienda, sino más bien iniciar el proceso en forma periférica, o como se dice en la práctica de la entrevista psicológica, seguir un proceso en espiral, esto es partir de interrogantes no directas con el tema de fondo, y progresivamente, de acuerdo a como se va desenvolviendo el testigo, ir avanzando hacia las partes nucleares.

- Asimismo no se debe abusar en exigir precisiones, sobre todo considerando que la evocación humana no siempre es fidedigna en detalles específicos. Sin embargo se observa que en la práctica del interrogatorio judicial, se piden minuciosidades al testigo sobre hechos acaecidos meses o años antes del momento en que declara, sobre todo en fechas y circunstancias, que como anota Emilio Mira, es «uno de los procesos psicológicos más inestables e influenciables, y por ello un sinfín de precisiones que los jueces acostumbran pedir a los testigos, referentes a fechas de acontecimientos, resultan absolutamente imposibles de satisfacer y sólo sirven para aumentar la confusión que pudiese ya existir $\rangle^{42}$, o bien para que el testigo invente o falsee datos.

\subsection{Interrogatorio del testigo en el fuero civil}

Se adopta una práctica algo diferente, en lo que concierne a la actuación de la prueba testimonial. Al respecto el Código Procesal Civil vigente, sigue en gran parte la formalidad del código anterior, y señala que la declaración del testigo es en función a un pliego interrogatorio que presenta la parte que ofrece el testigo. El Juez debe realizar el interrogatorio conforme a dicho pliego, sin embargo tiene la potestad de hacerle las preguntas que estime convenientes (Inc. 2 Art. 208 ${ }^{\circ}$ ). Del mismo modo, que las partes formulen en vía de aclaración. Asimismo pueden hacerle preguntas por sí o su abogado, y la otra parte tendrá igualmente oportunidad de plantearle contrapreguntas por sí o por intermedio de su abogado (Art. 227 ).

Generalmente este procedimiento no es muy adecuado, sobre todo cuando el testigo es amigo o conocido de la parte que lo propone, ya que en muchos casos es aleccionado previamente respecto a las pregun- 
tas del pliego y el sentido de las respuestas que debe dar, salvo los casos en que se solicite la concurrencia como testigo de alguien con el que no se tiene vinculación previa.

Si comparamos el tipo de interrogatorio en el proceso penal, no sujeto a un pliego interrogatorio, como el que se dispone en el Proceso Civil, podemos preguntarnos en cuál de las dos modalidades existen más errores al absolver las preguntas. En el estilo Narrativo libre o en el de tipo interrogatorio en base a un formato específico. Al respecto, parece que los testigos cometen mayor número de errores cuando las preguntas son cerradas que cuando se les permite el recuerdo libre ${ }^{43}$. Mira y Diges señalan también que "parece existir un acuerdo en que el recuerdo libre es mucho más seguro pero menos completo que contestar a preguntas cerradas, pero también que la aproximación más correcta para proceder a un interrogatorio es que el testigo cuente primero con sus propias palabras lo que ha visto y, luego, se le hagan preguntas sobre lo que no haya quedado claro o sobre otros detalles adicionales sobre los que se precisa información. Esto es, primero la forma narrativa y luego, en progresión, preguntas cada vez más estructuradas $[\ldots]{ }_{4}{ }_{4}^{4}$

Otro aspecto importante es el tipo de actitud en el interrogatorio, que puede ser inquisitivo y autoritario o bien más respetuosa de la persona del testigo y no autoritaria. Si recordamos las características del proceso mnémico, el entorno atemorizante del interrogador producirá un mayor bloqueo de la evocación y dificultará en general una adecuada declaración testimonial, condiciones que tendrán que graduarse, sin embargo, en función de las características personales del testigo.

43 Anne Anastasi. Psicología aplicada. Vol. 6, Buenos Aires, Ed. Kapelusz, 1970. 44 José Mira y Margarita Diges. Op. cit. 